\title{
The Pathogenicity of Cold and Heat Shocked Pasteurella multocida for Rabbit
}

\author{
Makarim K. A. Teirab $^{1 *}$, El Sanousi, S. M. ${ }^{2}$ and G. E. Mohamed ${ }^{1}$ \\ ${ }^{1}$ Department of Microbiology, Faculty of Veterinary Medicine, University of Sudan for \\ Science and Technology, Sudan \\ ${ }^{2}$ Department of Microbiology, Faculty of Veterinary Medicine, University of Khartoum, Sudan \\ *Corresponding author
}

\section{Keywords}

Pathogenicity, postmortemed, intra peritonealy, hemorrhagic septicaemia

\section{Article Info}

Accepted:

18 May 2020

Available Online:

10June 2020

\section{A B S T R A C T}

The purpose of this study was to study the pathogenecity of cold and heatshocked bacteria using Pasteurella multocida and rabbits as a model. Pasteurella multocida is an enigmatic pathogen. The capsule and lipopolysaccharide (LPS) of Pasteurella multocida constitute the major components of the bacterial cell surface; they play key roles in a range of interactions between the bacteria and the hosts they colonize or infect. Pasteurella multocida was inoculated into nutrient broth tubes and incubated at $37^{\circ} \mathrm{C}$ for 24 hours. The culture was shocked at $-15^{\circ} \mathrm{C}$ for 30 mins and ten serial dilutions were done. The dilutions which did not show visible colonies on the recovery media were centrifuged and inoculated intra peritonealy in four rabbits. The rabbits postmortemed and cultures were made from heart blood by puncturing with a sterile Pasteur pipette. The same test was repeated using treated culture at $50^{\circ} \mathrm{C}$ and $40^{\circ} \mathrm{C}$ for 10 mins such heat-treated cells did not lead to death of the inoculated rabbits.

\section{Introduction}

Many bacterial species have been found to exist in a viable but non-culturable (VBNC) state since the discovery in 1982. VBNC are characterized but loss of culturability in routine agar, which impairs their detection by conventional plate count techniques. This leads to an underestimation of total viable cells in environmental or clinical samples and thus poses a risk of public health (Laam, et al., 2014). Cold shock as defined by El
Sanousi (1975) comprises the injury, death or both which are caused by sudden chilling of the microorganisms.

The cold shock phenomenon occurs when growing bacteria are exposed to sudden temperature drop of at least $10^{\circ} \mathrm{C}$ leading to cold shock in susceptible microorganisms (Jones, et al., 1996). Collee, et al., (1961) termed the phenomenon as "phoenix" phenomenon due to disappearance of colonies at recovery medium and attributed this to the 
temperature of inoculums, a finding which was disqualified by El Sanousi (1975) who explained the phenomenon to be a mere cold shock one. This is due to cells being shocked when transferred from high temperature to low ones. Low temperature can influence the response of a microorganism either directly or indirectly.

Direct effects include decreased growth rate, enzyme activities, alteration of cell composition and differential nutritional requirements. Indirect effects are usually observed on the solubility of solute molecules, diffusion of nutrients, osmotic effects on membranes and cell density (Shekhar, 2011).

Heat treatment is one of the most widely used methods to control the rates of bacterial growth and death and is considered to be one of the most effective food processing technologies for eradicating food borne pathogens (Huang 2004), (Enache, et al., 2006). Definitions of pathogenicity: A pathogen or pathogenic microorganism is usually defined as a biological agent that can cause damage to its host during, or as a consequence of, the host- microorganism interaction. Damage may be inflicted directly by the microorganism (e.g. by toxins or other so-called virulence factors) or indirectly through the activity of the host immune responses (Casadevall and Pirofski, 1999).

The ability of the pathogen to infect is called its pathogenicity. Microorganisms express their pathogenicity by means of their virulence, a term that refers to the relative, quantitative degree of pathogenicity (Casadevall and Pirofski, 1999).

Moreover, pathogens are distinguished by their virulence from nonpathogen, which are considered to be a virulent (Casadevall and Pirofski, 1999).

\section{Materials and Methods}

The ingredients that were used included of blood agar as an enrichment medium, nutrient broth and normal saline. Pasteurella multocida was inoculated into nutrient broth tubes and incubated at $37^{\circ} \mathrm{C}$ for 24 hours. Ten serial dilutions in duplicate were performed. One of the duplicate was put in $37^{\circ} \mathrm{C}$; the other was shocked at $-15^{\circ} \mathrm{C}$ for $30 \mathrm{~min}$.

After incubation at $37^{\circ} \mathrm{C}$ for an overnight, the dilutions which did not show visible colonies on recovery media were centrifuged and inoculated $\mathrm{i} / \mathrm{p}$ in four rabbits. They were postmortemed and cultures were made from heart blood by puncturing with a sterile Pasteur pipette. The same test was repeated with bacteria heated at $50^{\circ} \mathrm{C}$ and $40^{\circ} \mathrm{C}$ for 10 mins.

\section{Results and Discussion}

Only cold-shocked cells showed their effect on the experimentally inoculated rabbits. Rabbits inoculated with VBNC bacteria died within 24 hours. They showed typical lesions of hemorrhagic septicaemia. Pasteurella multocida is an enigmatic pathogen. It is remarkable both for the number and range of specific disease syndromes with which it is associated, and the wide range of host species affected.

The pathogenic mechanisms involved in causing the different syndromes are, for the most part, poorly understood or completely unknown. The biochemical and serological properties of some organisms responsible for quite different syndromes appear to be similar.

Thus, the molecular basis for host predilection remains unknown. The recent development of genetic manipulation systems together with availability of multiple genome sequences 
should help to explain the association of particular hosts as well as helping to elucidate pathogenic mechanisms (Wilkie. et al., 2012). Cold-shocked P.multocida was able to resuscitate and cause death of inoculated rabbits. Such results are similar to those obtained by Nagla (2010) using P.multocida, E. coli, Salmonella spp and Staphylococcus aureus bacteria in that cold-shocked. P.multocida could retain its pathogenicity for rabbits.

Effective monitoring of microbial pathogen is essential for a successful preventive food safety and hygiene strategy. However, as most monitoring strategies are growth- based, these tests fail to detect pathogenic bacteria that have entered the viable but nonculturable (VBNC) state (Christian, et al., 2018).

Such information necessitates the importance of studies concerning (VBNC) bacteria. The capsule and lipopolysaccharide (LPS) of Pasteurella multocida constitute the major components of the bacterial cell surface. As well as forming the basis for the most widely used classification systems, they play key roles in a range of interactions between the bacteria and the hosts they colonize or infect. Both polysaccharides are involved in the avoidance of host innate immune mechanisms, such as resistance to phagocytosis, complement-mediated killing and the bacterial activity of antimicrobial peptides; they are there for essential for virulence.

In addition, LPS is a major antigen in the stimulation of adaptive immune responses to infection (Arumugam. et al., 2011).

It is concluded from this experiment that coldshocked Pasteurella multocida seemed to regain all pathogenic factors when they were resuscitated in the inoculated rabbits.

\section{Acknowledgment}

I would like to express my deepest gratitude to my advisor Professor Sulieman Mohamed El Sanousi for his unwavering support and encouragement, intellectual guideline; I shall treasure always. Also I should like to thank all the members of the department of Microbiology faculty of Veterinary Medicine, University of Khartoum for their technical assistance.

\section{References}

Arumugam, N. D., Ajam, N., blackall, P. J., Asiah, N. M., Ramlan, M., Maria, J., Yuslan, S., and Thong, K. L. (2011). Capsular serotyping of Pasteurella multocida from various animal hosts- a comparison of phenotypic and genotypic methods. Trop Bio med.28(1):55-63.

Casadevall.A, and Pirofski.L.A (1999).Hostpathogen interactions redefining the basic concepts of virulence and pathogenicity. Infect Immun67:37033713.

Christian, R., Susanne, F.,Anna, K.W., Dagmar, S., Peter, R and Patrick, $\mathrm{M}$ (2018). Science Reports. 8,1532.

Collee. J. G., Knowiden. J. A, and Hobbs. B. C (1961). Studies on the growth, sporulation and carriage of Clostridium welchii with special reference to food poisoning strains. J. Appl. Bacteriol. 24:326-339.

El Sanousi. (1975). Oxidation-reduction potential and growth of Colstridium perfringens. $\mathrm{PhD}$ thesis, university of Bristol country.

Enache E, Chen Y, Awuah76G,Economdes A, and Scott V N. (2006). Thermal Resistance Parameters for Pathogens in White Grape Juice Concentrate. J. Fd Protect69 (3): 564-56

Jones,P. G.,Mitta, M., Kim,Y., Jiang,W. and 
Inouye, M. (1996). Cold shock induces a major ribosomal associated protein that unwinds double-stranded RNA in Escherichia coli. Proc. Natl. Acad. Sci. 93:76-80.

Kataoka, E. E, Glenn Black.D, Lisa.W, Melinda.H, and Kristin.B.B. (2013). Heat resistance of histamine producing bacteria in irradiated tuna lions. $J . f d$ protect.(9):1604.

Laam, L, I., Nilmini, M., Hana, T., Jame, D,Q., and Sebastein, P.F.(2014).The importance of the viable but non culturable state in human bacterial pathogen. Frontiers in microbiology, 258.

Nagla, M.M.I. (2010). Physiological attributes of cold-shocked, Ecoli, Salmonella spp and Staphylococcus aureus and Pastuerella multocida.M.SC. University of Khartoum.

Shekhar. C. Bisht, (2011). Effect of Low Temperature on Bacterial Growth Category: Biology. 10:39-50.

Wilkie, I. W., Harper, M., Boyce, J.D and Adler,B (2012). Pasteurella multocida: Diseases and Pathogenesis. Springer. 361:1-22.

\section{How to cite this article:}

Makarim K. A. Teirab, El Sanousi, S. M and G. E. Mohamed. 2020. The Pathogenicity of Cold and Heat Shocked Pasteurella multocida for Rabbit. Int.J.Curr.Microbiol.App.Sci. 9(06): 24062409. doi: https://doi.org/10.20546/ijcmas.2020.906.295 